\title{
SISTEM KETATANEGARAAN INDONESIA PASCA AMANDEMEN UUD 1945
}

\author{
Sri Warjiati \\ Fakultas Syariah IAIN Sunan Ampel Surabaya
}

\begin{abstract}
The article discuss the changes of indonesian political system in indonesia after the amendment of Indonesian Constitution of 1945 with the focus of the amendments of legislative, eecutive and judicative bodies. Legislative amendments is located in the emergence of a new body called DPD (Dewan Perwakilan Daerah of Regional Representative Assembly) as a part of MPR (Majelis Permusyawaratan Rakyat or People's Consulatation Assembly) alongside DPR (Dewan Perwakilan Rakyat or House of Representative). Such amendment is basically a modifictaion of bicameral system as that of the United States' political system. Executive body amendments lies on direct election of president, limitation of presidential tenure up to two tenures of five years, and likeliness of presidential impeachment in case of breaking law and constitution. Amendment on judicative body is obviously apparent in the creation of Constitutional Court alongside the Supreme Court and Judicial comission which is in charge of safeguarding the judgeship profession.

Kata Kunci: Amandemen, UUD, dan System Ketatanegaraan.
\end{abstract}

\section{Pendahuluan}

Setelah UUD 1945 mengalami perubahan sebanyak empat kali, ${ }^{1}$ sistem ketatanegaraan Republik Indonesia juga mengalami perubahan. Perubahan terjadi dalam beberapa lembaga Negara, baik mengenai hubungan antara lembaga Negara, penambahan nama lembaga Negara baru, dan mengenai pembubaran lembaga Negara yang ada.

Perubahan pertama dilakukan pada tahun 1999, perubahan kedua tahun 2000, perubahan ketiga tahun 200I, dan perubahan keempat tahun 2002. 
Penambahan lembaga baru setelah amandemen UUD 1945 misalnya Mahkamah Konstitusi (MK), Komisi yudisial (KY), dan Dewan Perwakilan Daerah (DPD). Sedangkan pembubaran lembaga Negara setelah Amandemen semisal pembubaran Dewan Pertimbangan Agung (DPA).

Mahkamah Konstitusi (MK) merupakan lembaga yang berfungsi melaksanakan kekuasaan kehakiman di samping Mahkamah Agung (MA). Sedangkan Komisi Yudisial (KY) merupakan lembaga Negara yang berfungsi untuk menjaga martabat dan keluhuran hakim dan hakim agung.

Kekuasaan legislasi (membuat Undang-undang) sebelum amandemen UUD 1945 hanya dimiliki oleh Dewan Perwakilan Rakyat (DPR) dengan Presiden. Namun, setelah amandemen UUD 1945 di samping DPR, maka peran legislasi juga diberikan kepada Dewan Perwakilan Daerah (DPD) dalam hal-hal tertentu, sebagai lembaga Negara baru yang merupakan salah satu unsur dari Majelis Permusyawaratan Rakyat (MPR).

Atas dasar pemikiran di atas penulis tertarik membahas tentang "Sistem Ketatanegaraan Pasca Amandemen UUD 1945". Dengan demikian, akan diuraikan: kedudukan MPR, DPR, dan DPD pasca Amandemen UUD 1945; kedudukan MA, MK, KY pasca Amandemen; dan hubungan Presiden, DPR, dan MPR pasca Amandemen UUD 1945.

\section{Kedudukan MPR, DPR, dan DPD Pasca Amanden UUD 1945}

Kedukan MPR diatur dalam Pasal 2 dan 3 UUD 1945 hasil Amandemen. Pasal 2 UUD 1945 menyebutkan:

1. Majelis Permusyawaratan rakyat terdiri atas anggota Dewan Perwakilan Rakyat dan anggota Dewan Perwakilan Daerah yang dipilih melalui pemilihan umum dan diatur lebih lanjut dengan undang-undang.

2. Majelis Permusyawaratan Rakyat bersidang sedikitnya sekali dalam lima tahun di ibu kota Negara. 
3. Segala putusan Majelis Permusyawaratan Rakyat ditetapkan dengan suara yang terbanyak.

Sedangkan, Pasal 3 UUD menyebutkan:

1. Majelis Permusyawaratan Rakyat berwenang mengubah dan menetapkan Undang-undang Dasar.

2. Majelis Permusyawaratan Rakyat melantik Presiden dan/atau Wakil Presiden.

3. Majelis permusyawaratan Rakyat hanya dapat memberhentikan Presiden dan/atau Wakil Presiden dalam masa jabatanya menurut Undang-Undang Dasar.

Perubahan UUD 1945 membawa beberapa perubahan terhadap kedudukan MPR. Yaitu:

pertama, pergeseran kedudukan MPR dari lembaga tertinggi menjadi lembaga tinggi Negara. Sebelum Amandemen UUD 1945 MPR merupakan penyelenggara kedaulatan rakyat; dalam arti kedaulatan berada di tangan rakyat dan dilakukan sepenuhya oleh MPR, bahkan dalam penjelasan UUD 1945 disebutkan bahwa MPR ialah penyelnggara Negara yang teringgi. MPR dianggap sebagai penjelmaan rakyat yang memegang kedaulatan Negara. ${ }^{2}$

Kedua, perubahan tentang kenggotaan MPR. Sebelum UUD 1945 diamandemen kenggotaan MPR terdiri dari seluruh anggotan DPR, ditambah dengan utusan daerah, dan utusan golongan. Namun, setelah amandemen UUD 1945 keanggotaan MPR terdiri dari seluruh anggota DPR dan anggota DPD (Pasal 2 ayat (1)). Ketentuan tersebut sebenarnya ingin menjadikan lembaga perwakilan menjadi bicameral (dua kamar), seperti halnya di Amerika Serikat, di mana Senat sebagai perwakilan Negara bagian dan house of representative sebagai perwakilan dari masyarakat.

Ketiga, perubahan tentang kewenangan MPR. Sebelum amandemen UUD 1945 MPR, mempunyai wewewang memilih

${ }^{2}$ Penjelasan Pasal I UUD 1945 sebelum Amandemen.

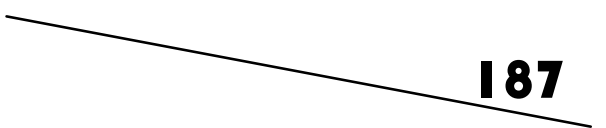


presiden dan/atau wakil Presiden; melantik Presiden dan/atau Wakil Presiden; melakukan sidang istimewa untuk memberhentikan Presiden dan/atau wakil presiden dalam masa jabatannya jika Presiden dan/atau wakil Presiden melanggar konstitusi, dan mengubah UUD. Namun, setelah amandemen UUD 1945 wewenang MPR meliputi mengubah dan menetapkan Undang-undang Dasar; melantik Presiden dan/atau Wakil Presiden; memberhentikan Presiden dan/atau Wakil Presiden dalam masa jabatanya menurut UndangUndang Dasar (Pasal 3 ayat (1), (2), (3).

Jika dilihat dari ketentuan tersebut hal yang mendasar adalah beralihnya kewenangan MPR untuk memilih Presiden dan/atau wakil Presiden kepada rakyat sebagai pemangku kedaulatan sepenuhnya. Sehingga beberapa pertanyaan muncul, "masih perlukah lembaga MPR?", "apakah merupakan keharusan Presiden dilantik oleh MPR, toh MPR bukan merupakan lembaga tertinggi?", "tidak cukupkah jika Presiden dilantik oleh ketua Mahkamah Agung?" Pertanyaan-pertanyaan tersebut kiranya merupakan pr bagi MPR untuk mengubah kembali UUD sehingga ada paradigma yang jelas dalam mengubah UUD 1945 yang tidak hanya tambal sulam. ${ }^{3}$

Kedudukan DPR diatur dalam Pasal 19, 20-22B UUD 1945 hasil Amandemen. Pasal 19 UUD menyebutkan:

1. Anggota Dewan Perwakilan Rakyat dipilih melalui pemilihan umum.

2. Susunan Dewan Perwakilan Rakyat diatur dengan undangundang.

3. Dewan Perwakilan Rakyat bersidang sedikitnya sekali dalam setahun.

Selama pemerintahan Soekarno (1959-1966) tidak pernah ada pemilu. Pada saat pemerintahan Soeharto, ada dua cara pengangkatan anggota DPR yaitu sebagian diisi melalui

${ }^{3}$ A. Muktie Arsyad, Amandemen UUD 1945 Antara Teks dan Konteks dalam Negara yang Sedang Berubah (Jakarta: Sinar Grafika, 2000), h. 25. 
pemilihan umum sebagai wakil rakyat, dan sebagian lagi diangkat. ${ }^{4}$

Praktek-praktek selama pemerintahan Soekarno dan Soeharto tidak sesuai dengan kehendak UUD 1945, walaupun naskah asli tidak mengatur secara tegas mengenai susunan dan keanggotaan DPR, dapat dipastikan penyusunan UUD 1945 menghendaki DPR hanya terdiri dari wakil-wakil partai politik dan diisi melalui pemilihan umum.

Sebelum Amandemen (dalam naskah asli UUD 1945) kekuasaan membentuk undang-undang ada pada presiden dan DPR memberikan persetujuanya. Berdasarkan bunyi pasal tersebut Hamid Attamimi berpendapat, kekuasaan membentuk undang-undang (legislative power) ada pada Presiden bukan pada DPR. ${ }^{5}$ Ketentuan dalam naskah asli UUD 1945 membingungkan dan mengandung anomaly. Selain anomaly dalam praktek ketatanegaraan, terutama pada masa pemerintahan Presiden Soeharto, ketentuan tersebut menimbulkan berbagai persoalan. Pertama, kekuasaan Presiden menjadi begiut kuat, termasuk menentukan isi dari suatu undang-undang. Kedua, ketentuan ini sangat mnegendurkan kemauan DPR untuk menggunakan hak inisiatif mengajukan rancangan undang-undang, walaupun hak ini dinyatakan dalam penjelasan UUD 1945. Ketiga, seolah-olah setiap rancangan undang-undang harus disetujui oleh DPR. ${ }^{6}$ Oleh karena itu dalam perubahan UUD Pasal 20 ayat (1),(2) disebutkan" Dewan Perwakilan Rakyat memegang kekuasaan membentuk undang-undang". "Setiap rancangan undang-undang dibahas oleh Dewan Perwakilan Rakyat dan Presiden untuk mendapatkan persetujuan bersama."

${ }^{4}$ Baqir Manan, DPR, DPD dan MPR dalam UUD 1945 Baru (Jogjakarta: UII Press, 2004), h. 14.

5 Hamid Attamimi, Peranan Keputusan Presiden Republik Indonesia dalam Penyelenggaraan Pemerintahan Negara, (Jakarta: Disertasi-Universitas Indonesia, 1990), h. 146.

${ }^{6}$ Baqir Manan, DPR, DPD dan MPR dalam UUD 1945 Baru, h. 23.

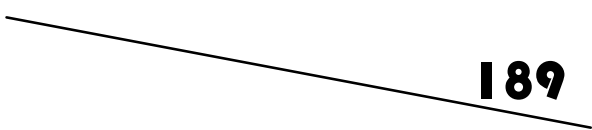


Berdasarkan ketentuan pasal tersebut kekuasaan membentuk undang-undang (legislative power) ada pada DPR (bukan pada presiden) untuk mendapatkan persetujan bersama presiden.

Dewan Perwakilan Daerah (DPD) merupakan lembaga baru dalam sistem ketatanegaraan Indonesia, munculnya DPD didasarkan pada hasil Amandemen UUD 1945 perubahan ketiga. Ada beberapa gagasan dibalik kelahiran DPD, yaitu:

Pertama, gagasan mengubah system perwakilan menjadi dua kamar (bicameral). DPD dan DPR digambarkan serupa dengan sistem perwakilan seperti di Amerika Serikat yang terdiri dari senate sebagai perwakilan Negara bagian, dan house of representative sebagai perwakilan seluruh DPR.

Kedua, gagasan untuk meningkatkan keikutsertaan daerah terhadap jalanya politik dan pengeloaan Negara. DPD merupakan badan sehari-hari yang turut serta menetukan dan mengawasi jalannya politik dan pengelolaan Negara. Dengan demikian, DPD dapat dipandang sebagai koreksi atau penyempurnaan sistem Utusan Daerah di MPR menurut Pasal 2 Ayat (1) UUD 1945 sebelum perubahan. ${ }^{7}$

Melihat ketentuan-ketentuan baru dalam perubahan UUD 1945 tidak nampak perwujudan gagasan sistem dua kamar, kalau dalam UUD asli hanya ada dua badan perwakilan tingkat pusat yang terpisah, sekarang setelah perubahan justru menjadi tiga badan perwakilan.

Tugas dan kewenangan DPD sebagai berikut:

1. DPD berhak mengajukan rancangan undang-undang kepada DPR yang berkaitan dengan otonomi daerah, hubungan pusat dan daerah, pembentukan dan pemekaran serta penggabungan daerah, pengelolaan sumber daya alam dan sumber daya ekonomi lainnya, serta yang berkaitan dengan perimbangan keuangan pusat dan daerah; 
2. DPD berwenang membahas rancangan undang-undang tertentu yang berkaitan dengan penyelenggaraan pemerintahan daerah;

3. DPD dapat melakukan pengawasan atas pelaksanaan undang-undang mengenai otonomi daerah.

\section{Kedudukan MA, MK dan KY Pasca Amandemen UUD 1945}

Setelah UUD 1945 diamandemen banyak pergeseran yang terjadi dalam sistem ketatanegaraan Indonesia, salah satunya adalah pergeseran dalam kekuasaan di bidang kehakiman, sebelum UUD 1945 diamandemen kekuasaan kehakiman hanya dilakukan oleh Mahkamah Agung dan lembaga peradilan di bawahnya. Akan tetapi setelah amandemen kekuasaan kehakiman dilakukan oleh Mahkamah Agung dan Mahkamah Konstitusi, sebagaimana diatur dalam ketentuan Pasal 24 UUD. Pasal 24 ayat (1) dan (2) UUD yang menyebutkan:

1. Kekuasaan kehakiman merupakan kekuasaan yang merdeka untuk menyelenggarakan peradilan guna menegakkan hukum dan keadilan.

2. Kekuasaan kehakiman dilakukan oleh sebuah Mahkamah Agung dan badan peradilan yang ada di bawahnya dalam lingkungan peradilan umum, lingkungan peradilan agama, lingkungan peradilan militer, lingkungan peradilan tata usaha Negara, dan oleh sebuah Mahkamah Konstitusi.

Ketentuan tersebut sesuai dengan prinsip negara hukum sebagaimana yang disebutkan dalam Pasal 1 ayat (3) UUD 1945 bahwa negara Indonesia adalah negara hukum. Dalam negara hukum suatu hal yang pokok adalah adanya pembatasan oleh hukum, dalam arti segala sikap, tindakan, dan tingkah laku baik yang dilakukan oleh para penguasa negara maupun oleh para warga negara harus berdasar pada ketentuan hukum. ${ }^{8}$

${ }^{8}$ Fathurrahman, Memahami Keberadaan Mahkamah Konstitusi di Indonesia (Bandung: Citra Aditya, 2004), h. 59.

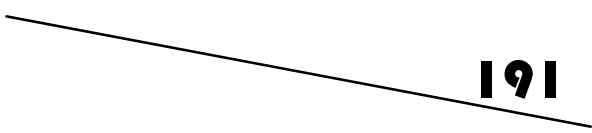


Untuk membatasi kekuasaan pemerintah, seluruh kekuasaan negara dalam pemerintah harus dipisahkan dan dibagi ke dalam kekuasaan dalam bidang tertentu. Mengenai pemisahan kekuasaan ada doktrin yang sangat populer yaitu Trias Politika. Dalam doktrin ini kekuasaan negara dipisahkan dalam tiga bidang, yaitu kekuasaan eksekutif, kekuasaan legislatif dan keukasaan yudikatif. Doktrin ini banyak dianut dan dikembangkan oleh berbagai negara dengan varian yang berbeda. Di Indonesia misalnya melalui keketentuan Pasal 24 UUD 1945, kekuasaan kehakiman dilakukan oleh Mahkamah Agung dan Mahkamah Konstitusi.

Dengan demikian, dapat disimpulkan bahwa kekuasaan kehakiman di Indonesia menganut sistem bifurkasi (bifurcation system), dimana kekuasaan kehakiman terbagi dalam dua cabang, yaitu cabang peradilan biasa (ordinary court) yang berpuncak pada Mahkamah Agung dan cabang peradilan konstitusi yang dijalankan oleh Mahkamah Konstitusi. ${ }^{9}$

Mahkamah Agung dan Mahkamah Konstitusi sebagai pelaku kekuasaan kehakiman mempunyai wewenang masingmasing. Wewenang Mahkamah Agung sebagaimana diatur dalam pasal 24 A UUD 1945 yang menyebutkan:

"Mahkamah Agung berwenang mengadili pada tingkat kasasi, menguji peraturan perundang-undangan di bawah undang-undang terhadap undang-undang, dan mempunyai kewenangan lainnya yang diberikan oleh undang-undang".

Wewenang Mahkamah Agung dalam soal kekuasaan mengadili meliputi:

1. Mengadili dalam tingkat pertama dan terakhir, mengenai:

a. Perselisihan yuridiksi (kekuasaan mengadili) antara badan peradilan dalam lingkungan yang berbeda; 
b. Perselisihan yuridiksi antara badan-badan peradilan yang sederajat yang termasuk wewenang Pengadilan Tinggi yang berlainan;

c. Semua sengketa mengenai wewenang mengadili yang tidak termasuk butir di atas.

2. Mengadili dalam tingkat kasasi, mengenai:

a. Perkara-perkara yang dimohonkan kasasi dalam semua lingkungan peradilan.

b. Melakukan pengujian materiil terhadap peraturan perundangan di bawah undan-undang.

c. Melakukan peninjauan kembali perkara-perkara yang dimohonkan peninjauan kembali.

d. Memberikan putusan dalam tingkat pertama dan terakhir, semua sengketa yang timbul karena perampasan kapal asing dan muatannya oleh kapal perang ${ }^{10}$.

Pertama, Mahkamah Agung berwenang memeriksa dan memutus sengketa tentang kewenangan mengadili antara badan peradilan di bawahnya. Fungsi ini menunjukkan peran Mahkamah Agung dalam kedudukannya sebagai Pengadilan Negara tertinggi, semua Pengadilan berpuncak di Mahkamah Agung. Hal ini telah menjadi asas dalam menata sistem kekuasaan kahakiman di Indonesia.

Kedua, Mahkamah Agung memutus perkara kasasi terhadap putusan Pengadilan Banding atau tingkat terakhir dari semua lingkungan Peradilan. Mahkamah Agung dalam tingkat kasasi membatalkan putusan atau penetapan Pengadilanpengadilan dari semua lingkungan Peradilan karena:

1. Tidak berwenang atau melampaui batas wewenang;

2. Salah menerapkan atau melanggar hukum yang berlaku;

3. Lalai memenuhi syarat-syarat yang diwajibkan oleh peraturan perundang-undangan yang mengancam kelalaian itu dengan batalnya putusan yang bersangkutan ${ }^{11}$.

${ }^{10}$ Philipus M. Hadjon, Lembaga Tertinggi dan Lembaga-lembaga Tinggi Negara Menurut UUD 1945 Suatu Analisa Hukum (Surabaya: PT Bina Ilmu, 1992), h. 59.

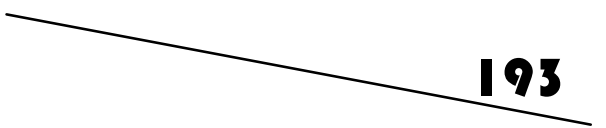


Istilah kasasi berasal dari bahasa Perancis "casser" yang berarti memecahkan atau membatalkan, sehingga kalau permohonan kasasi terhadap suatu putusan pengadilan bawahan itu diterima oleh Mahkmah Agung berarti putusan itu dibatalkan oleh Mahkamah Agung karena dianggap mengandung kesalahan dalam penerapan hukumnya. Dengan demikian, Mahkamah Agung tidak memeriksan yudex factie akan tetapi hanya memeriksa tentang penerapan hukumnya, karena masalah yudex factie itu merupakan wewenang pengadilan tingkat pertama dan pengadilan tingat banding.

Ketiga, Mahkamah Agung memeriksa dan memutus permohonan peninjaun kembali pada tingkat pertama dan terakhir atas putusan Pengadilan yang telah memperoleh kekuatan hukum tetap dalam perkara perdata berdasarkan alasan-alasan:

1. Apabila putusan didasarkan pada suatu kebohongan atau tipu muslihat pihak lawan yang diketahui setelah perkaranya diputus atau didasarkan pada bukti-bukti yang kemudian oleh hakim pidana dinyatakan palsu;

2. Apabila setelah perkara diputus, ditemukan surat-surat bukti yang bersifat menentukan yang pada waktu perkara diperiksa tidak dapat ditemukan (novum);

3. Apabila telah dikabulkan suatu hal yang tidak dituntut atau lebih dari pada yang dituntut;

4. Apabila mengenai suatu bagian dari tuntutan belum diputus tanpa dipertimbangkan sebab-sebabnya;

5. Apabila antara pihak-pihak yang sama mengenai suatu soal yang sama, atas dasar yang sama oleh Pengadilan yang sama atau sama tingkatannya telah diberikan putusan yang bertentangan satu dengan yang lain;

6. Apabila dalam suatu putusan terdapat kekhilafan hakim atau suatu kekeliruan yang nyata ${ }^{12}$.

"A. Mukti Arto, Konsepsi Ideal Mahkamah Agung (Yogyakarta: Pustaka Pelajar, 200 I), h. 225.

12/bid., h. 229. 
Sedangkan dalam perkara pidana, terhadap putusan pengadilan yang telah memperoleh kekuatan hukum tetap, kecuali putusan bebas atau lepas dari segala tuntutan hukum, terpidana atau ahli warisnya dapat mengajukan permintaan Peninjauan Kembali kepada Mahkamah Agung.

Keempat, Mahkamah Agung berwenang menguji secara materiil (yudicial review) peraturan perundang-undangan di bawah undang-undang. Wewenang menguji peraturan perundang-undangan yang dimiliki oleh Mahkamah Agung hanya terhadap peraturan perundang-undangan yang tingkatannya di bawah undang-undang, yaitu: Peraturan Pemerintah, Peraturan Presiden, Peraturan Menteri, dan Peraturan Daerah. Dalam hal ini Mahkamah Agung hanya berwenang menyatakan bahwa peraturan-peraturan tersebut tidak sah, sedangkan pencabutan terhadap peraturan yang dinyatakan tidak sah dilakukan oleh instansi yang bersangkutan ${ }^{13}$. Apabila Mahkamah Agung mengabulkan permohonan dari pemohon untuk menguji sebuah peraturan perundang-undangan di bawah undang-undang, maka Mahkamah Agung dalam amar putusannya menyatakan bahwa suatu peraturan perundang-undangan dari tingkatan yang lebih rendah dari pada Undang-undang bertentangan dengan peraturang perundang-undangan yang lebih tinggi (Undangundang), dan Mahkamah Agung secara tegas menyatakan bahwa peraturan tersebut tidak sah dan tidak berlaku untuk umum $^{14}$.

Kelima, Mahkamah Agung berwenang memutus dalam tingkat pertama dan terakhir semua sengketa yang timbul karena perampasan kapal asing dan muatannya oleh kapal perang Republik Indonesia berdasarkan peraturan yang berlaku. Yang dimaksud dengan kapal perang di sini ialah kapal laut dan kapal udara. Ketentuan ini memberikan dasar

${ }^{13}$ Philipus M. Hadjon, Lembaga Tertinggi, h.6I.

${ }^{14} \mathrm{~A}$. Mukti Arto, Konsepsi Ideal, h. 23I.

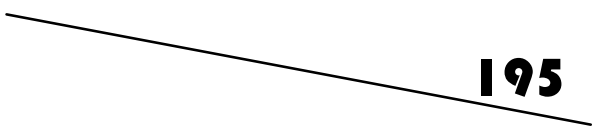


hukum dan kewenangan mengadili (Atribute van rechtsonacht) kepada Mahkamah Agung untuk memeriksa dan memutus sengketa yang timbul karena perampasan kapal oleh kapal perang RI demi tegaknya negara hukum Republik Indonesia ${ }^{15}$.

Sedangkan wewenang Mahkamah Konstitusi sebagaimana diatur dalam Pasal 24 C ayat (1) dan ayat (2) UUD 1945, yaitu mengadili dan memutus pada tingkat pertama dan terakhir yang putusanya bersifat final untuk:

1. Menguji Undang-undang terhadap Undang-Undang Dasar (judicial review);

2. Memutus sengketa kewenangan lembaga negara yang kewenangannya diberikan oleh Undang-Undang Dasar;

3. Memutus pembubaran partai politik;

4. Memutus perselisihan tentang hasil pemilu;

5. Memutus perselisihan hasil pilkada.

Di samping itu, Mahkamah Konstitusi wajib memeriksa, mengadili dan memutus pendapat Dewan Perwakilan Rakyat, bahwa presiden dan/atau wakil presiden diduga melakukan pelanggaran hukum dan/atau tidak lagi memenuhi syarat sebagai presiden dan/atau wakil presiden. Pasal 24C UUD menyebutkan:

1. Mahkamah Konstitusi berwenang mengadili pada tingkat pertama dan terakhir yang putusannya bersifat final untuk menguji undang-undang terhadap Undang-undang Dasar, memutus sengketa kewengan lembaga Negara yang kewenangannya diberikan oleh Undang-undang Dasar, memutus pembubaran partai politik, dan memutus perselisihan tentang hasil pemilihan umum.

2. Mahkamah Konstitusi wajib memberikan putusan atas pendapat Dewan Perwakilan Rakyat mengenai dugaan pelanggaran oleh presiden dan/atau wakil presiden menurut Undang-undang Dasar.

15/bid., h. 230. 
Dengan demikian, antara Mahkamah Agung dan Mahkamah Konstitusi merupakan dua lembaga negara yang sejajar dan keduanya adalah pelaku kekuaasaan kehakiman di Indonesia namun berbeda dari segi yuridiksi dan kompetensinya. Sampai saat ini, MK telah melaksanakan dari empat wewenang yang ada pada dirinya, yaitu menguji Undang-undang terhadap UUD (yudicial review), memutus perselisihan hasil pemilu, dan memutus sengketa kewenangan lembaga negara yang diatur oleh UUD. Sedangkan satu wewenang MK belum dilaksanakan karena memang sampai saat ini belum ada permohonan mengenai hal itu yang masuk ke MK, yaitu memutus pembubaran partai politik. Seiring dengan itu sampai saat ini kewajiban MK juga belum dilaksanakan karena sampai saat ini belum ada permohonan dari DPR yang berisi pendapat lembaga legislatif terkait dengan impeachment presiden dan/atau wakil presiden ${ }^{16}$.

Komisi Yudisial merupakan lembaga mandiri dan independen, susunan keanggotaannya dipilih dari orang-orang yang memilki integritas yang teruji. Munculnya gagasan untuk membentuk Komisi Yudisial berangkat dari keinginan sebagai berikut:

1. Meningkatkan pengawasan proses peradilan secara transparan;

2. Meningkatkan partisipasi masyarakat dalam rangka pengawasan dan pembenahan sistem manajemen dan administrasi peradilan secara terpadu;

3. Menyusun sistem rekrutmen dan promosi yang lebih ketat;

4. Mengembangkan pengawasan terhadap proses rekrutmen dan promosi;

5. Meningkatkan kesejahteraan hakim melalui peningkatan gaji dan tunjangan-tunjangan lainnya;

${ }^{16}$ Jimly Asshiddiqy, "Mahkamah Konstitusi dalam Sistem ketatanegaraan Republik Indonesia", Makalah disampaikan dalam kuliah Umum di Universitas Brawijaya, Malang, 29 September 2005, h. 27.

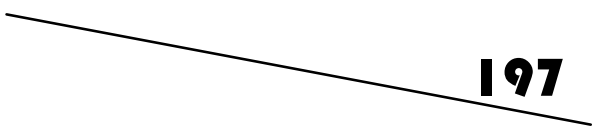


6. Membentuk dewan kehormatan hakim untuk melakukan fungsi pengawasan. ${ }^{17}$

Komisi Yudisial mempunyai wewenang untuk menjaga kehormatan, keluhuran martabat, serta perilaku hakim agung; dan menegakkan kehormatan, keluhuran martabat dan perilaku hakim agung. Sedangkan tugas Komisi Yudisial berdasarkan ketentuan Pasal 24 B UUD 1945 adalah mengusulkan pengangkatan hakim agung; dan wewenang lain dalam rangka menjaga dan menegakkan keluhuran martabat, serta perilaku hakim. ${ }^{18}$ Ada sebagian kalangan yang berpendapat berdasarkan ketentuan Pasal 24 B tersebut Komisi Yudisial diberikan kewenangan untuk melakukan promosi dan mutasi hakim, pendidikan dan pelatihan hakim, dan manajemen keuangan hakim sebagaimana praktik di beberapa negara.

\section{Hubungan Presiden, DPR, dan MPR Pasca Amandemen 1945}

Sebelum menjelaskan tentang hubungan antara Presiden, DPR dan MPR terlebih dulu perlu dijelaskan tentang kedudukan Presiden menurut UUD hasil Amandemen, yang dijelaskan dalam Pasal 4, 5, dan 7. Pasal 4 UUD menyebutkan:

1. Presiden Republik Indonesia memegang kekuasaan pemerintahan menurut Undang-undang Dasar.

2. Dalam melakukan kewajibannya Presiden dibantu satu orang wakil Presiden.

Menurut ketentuan Pasal 4 UUD, Presiden memegang kekuasaan eksekutif tertinggi. Di samping itu Presiden juga merupakan kepala negara dan kepala pemerintahan. Dalam menjalankan tugasnya Presiden dibantu oleh satu orang wakil Presiden yang dipilih bersama-sama satu paket dengan presiden dalam pemilihan umum secara langsung. Menurut Jimliy Asshidiqy seperti dikutip Teguh Satya Bhakti

\footnotetext{
${ }^{17}$ A. Ahsin Thohari, Komisi Yudisial\&Reformasi Peradilan (Jakarta: ELSAM, 2004), h. 166.

${ }^{18} /$ bid., h. 172.
} 
menyatakan bahwa dalam sistem presidensiil terdapat 5 (lima) prinsip penting, yaitu: ${ }^{19}$

1. Presiden dan wakil Presiden merupakan satu institusi penyelenggara kekuasaan eksekutif negara yang teringgi di bawah UUD;

2. Presiden dan wakil presiden dipilih secara langsung oleh rakyat dan karena itu secara politik tidak bertanggungjawab kepada MPR atau lembaga parlemen, melainkan bertanggung jawab langsung kepada rakyat yang memilihnya;

3. Presiden dan/atau wakil presiden dapat dimintakan pertanggunjawabannya secara hukum apabila presiden dan/atau wakil presiden melakukan pelanggaran hukum dan konstitusi;

4. Para menteri adalah pembantu presiden, menteri diangkat dan diberhentikan oleh presiden dan karena itu bertanggung jawab kepada Presiden, bukan dan tidak bertanggung jawab kepada parlemen;

5. Untuk membatasi kekuasaan presiden yang kedudukannya dalam sistem presidensial sangat kuat sesuai kebutuhan untuk menjamin stabilitas pemerintahan, ditentukan pula bahwa masa jabatan Presiden lima tahunan tidak boleh dijabat oleh orang yang sama lebih dari dua masa jabatan.

Selanjutnya ciri khas dari sistem pemerintahan presidensiil adalah:

1. Presiden adalah kepala negara dan kepala pemerintahan yang tidak dapat diganggu gugat.

2. Presiden menjalankan kekuasaannya selama 5 (lima) tahun tanpa terganggu dengan kewajiban memberi pertanggungjawaban kepada MPR pada masa jabatannya.

3. Hubungan presiden dengan lembaga negara lainnya diatur berdasarkan sistem checks and balances yang kuat, yang

${ }^{19}$ Teguh Satya Bhakti, "Pola Hubungan Presiden dan DPR Menurut Perubahan UUD 1945", dalam Jurnal Konstitusi, Vol 6, No. 4, November 2009, h. I 17-I 46.

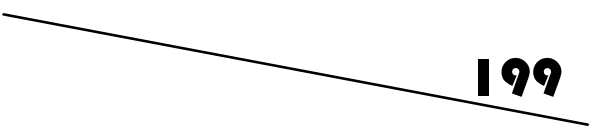


saling mengawasi dan saling mengimbangi diantara lembaga-lembaga negara.

4. Impeachment, sebagaimana tertuang dalam penjelasan UUD 1945, bahwa semua anggota DPR adalah juga menjadi anggota MPR, oleh karena itu DPR dapat senantiasa mengawasi tindakan-tindakan Presiden, jika DPR menganggap Presiden sungguh-sungguh melanggar konstitusi, maka majelis dapat diundang untuk melakukan sidang istimewa untuk minta pertanggungjawaban Presiden. Dalam sidang istimewa tersebut MPR dapat mencabut kekuasaan dan/atau memberhentikan Presiden ${ }^{20}$.

Mengenai masa jabatan presiden dan wakil presiden, diatur dalam Pasal 7 UUD yang menyebutkan: "Presiden dan wakil presiden memegang jabatan selama 5 (lima) tahun, dan sesudahnya dapat dipilih kembali dalam jabatan yang sama, hanya untuk satu kali masa jabatan."

Mengenai pemilihan Presiden setelah amandemen UUD, ditegaskan bahwa Presiden dan wakil Presiden dipilih secara langsung oleh rakyat untuk masa jabatan lima tahun. Hal ini berbeda dengan pemilihan Presiden sebelum amandemen UUD, di mana Presiden dipilih oleh anggota Majelis Permusyawaratan Rakyat. Ini berarti, setelah amandemen, pada dasarnya Presiden tidak lagi bertanggungjawab kepada MPR yang terdiri dari dua kamar (bicameral) yang ada, yakni Dewan Perwakilan Rakyat dan Dewan Perwakilan Daerah. Dengan demikian, selama 5 (lima) tahun masa jabatanya, kedudukan Presiden tidak dapat diganggu gugat. Kontruksi semacam ini telah menghentikan konflik ketatanegaraan yang selama ini mewarnai sistem pemerintahan di Indonesia ${ }^{21}$.

${ }^{20}$ Anonimous, Bahan Penjelasan Badan Pekerja MPR dalam Rangka Memasyarakatkan Hasil Sidang Umum MPR 1999 dan Sidang Tahunan MPR 2000, (Jakarta: Sekretariat Jenderal MPR RI, 2000), h. I0-11.

${ }^{21}$ Teguh Satya Bhakti, Pola Hubungan Presiden dan DPR, h. 122. 
Hubungan Presiden dan DPR dapat dikelompokkan dalam 3 (tiga) bidang, yaitu bidang legislasi, bidang anggaran dan bidang pengawasan. Dalam bidang legislasi hubungang Presiden dan DPR diatur dalam Pasal 5, Pasal 20 dan Pasal 22 UUD. Pasal 5 UUD menyebutkan:

1. Presiden berhak mengajukan rancangan undang-undang kepada Dewan Perwakilan Rakyat.

2. Presiden menetapkan peraturan pemerintah untuk menjalankan undang-undang sebagaiman mestinya.

Sedangkan Pasal 22 menyebutkan:

1. Dalam hal ihwal kegentingan yang memmaksa, Presiden berhak menetapkan Peraturan Pemerintah sebagai Pengganti Undang-undang.

2. Peraturan Pemerintah itu harus mendapat persetujuan Dewan Perwakilan Rakyat dalam persidangan berikut.

3. Jika tidak mendapat persetujuan maka Peraturan Pemerintah itu harus dicabut.

Setelah Amandemen UUD terjadi pergeseran dalam kekuasaan membentuk undang-undang yang selama ini dikenal dengan kekuasaan legislative. Dalam ketentuan Pasal 5 UUD sebelum amandemen disebutkan "Presiden memegang kekuasaan membentuk undang-undang dengan persetujuan DPR", akan tetapi dalam amandemen UUD, rumusan Pasal tersebut diubah menjadi "Presiden berhak mengusulkan rancangan undang-undang kepada DPR". Jika dihubungkan dengan ketentuan Pasal 20 ayat (1) UUD hasil amandemen dinyatakan: "DPR memegang keukasaan untuk membentuk undang-undang". Dengan demikian telah terjadi pergeseran paradigma dalam kekuasaan membentuk undang-undang, kalau sebelum amandemen kekuasaan membentuk undangundang berada di tangan Presiden, akan tetapi setelah amandemen berada di tangan DPR. ${ }^{22}$

22 /bid., h. 129. Lihat juga: Baqir Manan, DPR, DPD, dan MPR, h. 23.

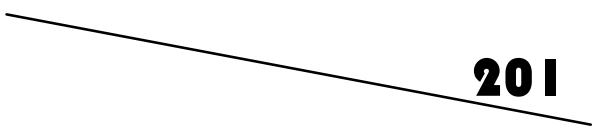


Hubungan Presiden dan DPR di bidang anggaran diatur dalam Pasal 23 UUD. Pasal 23 menyebutkan:

1. Anggaran Pendapatan dan Belanja Negara sebagai wujud dari pengelolaan keuangan negara ditetapkan setiap tahun dengan undang-undang dan dilaksanakan secara terbuka dan bertanggung jawab untuk sebesar-besarnya kemakmuran rakyat.

2. Rancangan undang-undang Anggaran Pendapatan dan Belanja Negara diajukan oleh Presiden untuk dibahas bersama Dewan Perwakilan Rakyat dengan memperhatikan perttimbangan Dewan Perwakilan Rakyat.

3. Apabila Dewan Perwakilan Rakyat tidak menyetujui rancangan anggaran pendapatan dan belanja negara yang diusulkan oleh Presiden, pemerintah menjalankan anggaran Pendapatan dan Belanja Negara tahun lalu.

Ketentuan tersebut berkaitan dengan fungsi anggaran yang dimiliki oleh DPR. Fungsi anggaran ini sangat penting karena berkaitan dengan masalah anggaran negara yang akan digunakan untuk melaksanakan pembangunan. Ketentuan pasal tersebut menunjukkan bahwa Pemerintah baru dapat melaksanakan APBN setelah mendapatkan persetujuan DPR, oleh karena DPR memegang kedaulatan di bidang budget, jadi persetujuan DPR terhadap APBN yang diusulkan oleh Pemerintah ini merupakan kuasa (machtiging) dan bukan merupakan consent DPR. ${ }^{23}$

Dalam melaksanakan fungsinya, DPR mempunyai hak interpelasi, hak angket dan hak menyatakan pendapat. Fungsi pengawasan yang dilakukan oleh DPR dapat berimplikasi impeacmant terhadap presiden apabila presiden terbukti melakukakan tindak pidana korupsi, penyuapan dan tindak pidana berat lainya dengan terlebih dahulu meminta pendapat Mahkamah Konstitusi. Namun demikian, presiden tidak dapat

${ }^{23}$ Teguh Satya Bhakti, Pola Hubungan Presiden dan DPR, h. 132.

$202 \mid$\begin{tabular}{l|l} 
al-Daulah \\
Vol. 2. no.2. Oktober 2012
\end{tabular} 
membubarkan DPR sebagaimana diatur dalam Pasal 7 C UUD. Pasal 7C menyebutkan:

"Presiden tidak dapat membekukan dan/atau membubarkan Dewan Perwakilan Rakyat". Praktek ketatanegaraan yang pernah terjadi di Indonesia, mantan Presiden Abdurrahman Wahid pernah mengeluarkan maklumat yang isinya membubarkan DPR. Atas dasar itu kemudian dalam amandemen UUD 1945 pasal 7 dicantumkan bahwa Presiden tidak dapat membekukan DPR.

Dalam rangka fungsi pengawasan terhadap presiden, DPR dapat mengusulkan pemberhentian presiden dengan terlebih dulu mengajukan ke Mahkamah Konstitusi untuk memutus dugaan DPR terhadap penyimpangan yang dilakukan oleh Presiden, sebagimana diatur dalam pasal 7A, yang menyebutkan:

"Presiden dan/atau wakil presiden dapat diberhentikan dalam masa jabatanya oleh Majelis Permusyawaratan Rakyat atas usul Dewan Perwakilan Rakyat, baik apabila terbukti telah melakukan pelanggaran hukum berupa penghianatan terhadap Negara, korupsi, penyuapan, tindak pidana berat lainya, atau perbuatan tercela maupun apabila terbukti tidak lagi memenuhi syarat sebagai presiden dan/atau wakil presiden".

Berdasarkan ketentuan Pasal 7A UUD tersebut, ada dua alasan presiden dan/atau wakil presiden dapat diberhentikan dalam masa jabatannya, yaitu:

1. Melakukan pelanggaran hukum yang berupa:

a. Penghianatan terhadap negara;

b. Korupsi;

c. Penyuapan;

d. Tindak pidana berat lainnya atau;

e. Perbuatan tercela.

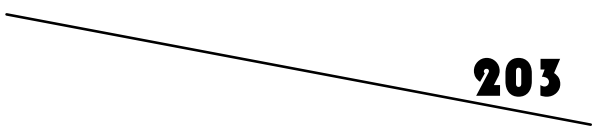


2. Terbukti tidak lagi memenuhi syarat sebagai presiden dan/atau wakil presiden ${ }^{24}$.

Undang-undang Dasar tidak memberikan penjelasan apa yang dimaksud dengan jenis-jenis pelanggaran hukum yang tercantum dalam Pasal 7A tersebut. Penjelasan tentang jenisjenis pelanggaran hukum tersebut tercantum dalam Undangundang tentang Mahkamah Konstitusi sebagaimana berikut:

1. Penghianatan terhadap negara adalah tindak pidana terhadap keamanan negara sebagaimana diatur dalam undang-undang.

2. Korupsi dan penyuapan adalah tindak pidana korupsi atau penyuapan sebagaimana diatur dalam undang-undang;

3. Tindak pidana berat lainya adalah tindak pidana yang diancam dengan pidana penjara 5 (lima) tahun atau lebih;

4. Perbuatan tercela adalah perbuatan yang dapat merendahkan martabat presiden dan/atau wakil presiden ${ }^{25}$.

Sedangkan, Pasal 7 B ayat (1) menyebutkan:

"Usul pemberhentian presiden dan/atau wakil presiden dapat diajukan oleh dewan Perwakilan Rakyat kepada Majelis Permusyawaratan Rakyat hanya dengan terlebih dahulu mengajukan permintaan kepada Mahkamah Konstitusi untuk memeriksa, mengadili, dan memutus pendapat Dewan Perwakilan Rakyat bahwa Presiden dan/atau Wakil Presiden telah melakukan pelanggaran hukum berupa penghianatan terhadap Negara, korupsi, penyuapan, tindak pidana lainnya, atau perbuatan tercela, dan/atau pendapat bahwa presiden dan/atau wakil presiden tidak lagi memenuhi syarat sebagai Presiden dan/atau Wakil Presiden".

Undang-undang Mahkamah Konstitusi hanya mengatur tentang mekanisme pengajuan permohonan, yaitu diajukan oleh DPR sebagai pemohon. DPR dalam mengajukan permohonan

${ }^{24} \mathrm{Hamdan}$ Zoelva, Impeachment Presiden Alasan Tindak Pidana Pemberhentian Presiden Menurut UUD 1945 (Jakarta: KONPress, 2005), h.5I.

${ }^{25}$ Pasal 10 ayat (3) Undang-undang Nomor 24 Tahun 2003 tentang Mahkamah Konstitusi. 
harus dilakukan secara tertulis dan menguraikan secara jelas mengenai dugaan pelanggaran hukum yang dilakukan oleh presiden dan/atau wakil presiden kepada Mahkamah Konstitusi dan melampirkan putusan dan dan proses pengambilan keputusan di DPR, risalah atau berita acara di DPR serta bukti mengenai dugaan pelanggaran yang dilakukan oleh presiden dan/atau wakil presiden. ${ }^{26}$ Oleh karena itu untuk mengisi kekosongan hukum acara di Mahkamah Konstistusi tentang mekanisme pengajuan pemeriksaan terhadap dugaan DPR terhadap pelanggaran hukum yang dilakukan oleh presiden dan/atau wakil presiden, Mahkamah Konstitusi mengeluarkan Peraturan Mahkamah Konstitusi yang mengatur secara rinci proses pemeriksaan perkara permohonan DPR.

Dalam hal Mahkamah Konstitusi memutuskan bahwa pendapat DPR itu tidak berdasarkan hukum, maka proses pemberhentian presiden itu menjadi gugur dan sebaliknya jika MK membenarkan pendapat DPR, maka DPR tinggal meneruskannya kepada MPR untuk dijatuhkan putusan memberhentian atau tidak memberhentikan Presiden. ${ }^{27}$ Dengan demikian, pemberhentian presiden menurut UUD 1945 Hasil amandemen harus melewati 3 (tiga) lembaga negara, yaitu DPR, MK, dan MPR. Ketiga lembaga ini mempunyai kewenangan berbeda, DPR melakukan penyelidikan dan mencari bukti-bukti dan fakta yang mengukuhkan dugaan adanya pelanggaran pasal pemeberhentian presiden (Pasal 7A UUD 1945) serta mengajukan usul pemberhentian kepada MPR. Mahkamah Konstitusi sebagai lembaga yang memutuskan dugaan DPR terhadap pelanggaran hukum yang dilakukan oleh presiden, dan MPR sebagai lembaga yang memberikan keputusan tentang pemberhentian presiden melalui sidang Istimewa.

${ }^{26}$ Hamdan Zoelva, Impeachment Presiden, h. 74.

27 lbid., h.70.

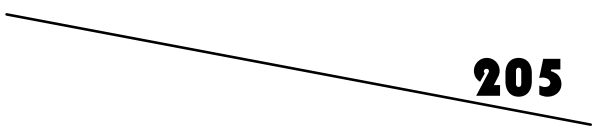




\section{Penutup}

Berdasarkan uraian di muka, dapat diambil kesimpulan, bahwa Amandemen UUD 1945 membawa perubahan dalam sistem ketatanegaraan di Indonesia.

Pertama, kedudukan MPR setelah amandemen UUD 1945 bukan merupakan lembaga tertinggi negara, akan tetapi lembaga tinggi negara sebagaimana DPR dan lembaga negara lainya. Sedangkan susunan keanggotaan MPR setelah amandemen UUD 1945 terdiri anggota DPR dan DPD.

Kedua, kekuasaan kehakiman berdasarkan ketentuan UUD 1945 hasil amandemen dilakukan oleh Mahkamah Agung dan Mahkamah konstitusi, di samping itu dibentuk Komisi Yudisial yang berwenang menjaga martabat dan keluhuran hakim Agung.

Ketiga, hubungan DPR dan Presiden terbagi dalam tiga bidang yaitu; legislasi, anggaran dan pengawasan. Dalam melaksanakan pengawasan terhadap presiden, DPR dapat meminta MPR untuk memberhentikan presidem dalam masa jabatanya, apabila terbukti melakukan tindak pidana korupsi, penyuapan dan/atau tindak pidana berat lainya. Akan tetapi dugaan DPR atas pelanggaran hukum/konstitusi yang dilakukan oleh presiden harus diputus terlebih dahulu oleh Mahkamah Konstitusi sebelum diajukan ke sidang Istimewa MPR.

\section{Daftar Pustaka}

A. Ahsin Thohari, Komisi YudisialeReformasi Peradilan, Jakarta, ELSAM, 2004.

A. Mukti Arto, Konsepsi Ideal Mahkamah Agung, Yogyakarta, Pustaka Pelajar, 2001.

A. Muktie Arsyad, Amandemen UUD 1945 Antara Teks dan Konteks dalam Negara yang Sedang Berubah, Jakarta, Sinar Grafika, 2000. 
Anonimous, Bahan Penjelasan Badan Pekerja MPR dalam Rangka Memasyarakatkan Hasil Sidang Umum MPR 1999 dan Sidang Tahunan MPR 2000, Jakarta, Sekretariat Jenderal MPR RI, 2000.

Baqir Manan, DPR, DPD dan MPR dalam UUD 1945 Baru, Jogjakarta, UII Press, 2004.

Fathurrahman, Memahami Keberadaan Mahkamah Konstitusi di Indonesia, Bandung, Citra Aditya, 2004.

Hamdan Zoelva, Impeachment Presiden Alasan Tindak Pidana Pemberhentian Presiden Menurut UUD 1945, Jakarta, KONPress, 2005.

Hamid Attamimi, Peranan Keputusan Presiden Republik Indonesia dalam Penyelenggaraan Pemerintahan Negara, Jakarta, Disertasi-Universitas Indonesia, 1990.

Jimly Asshiddiqy, "Mahkamah Konstitusi dalam Sistem ketatanegaraan Republik Indonesia", Makalah disampaikan dalam kuliah Umum di Universitas Brawijaya, Malang, 29 September 2005.

Philipus M. Hadjon, Lembaga Tertinggi dan Lembaga-lembaga Tinggi Negara Menurut UUD 1945 Suatu Analisa Hukum, Surabaya, PT Bina Ilmu, 1992.

Teguh Satya Bhakti, "Pola Hubungan Presiden dan DPR Menurut Perubahan UUD 1945", dalam Jurnal Konstitusi, Vol 6, No. 4, November 2009.

\section{Peraturan Perundang-undangan:}

Undang-undang dasar Negara Republik Indonesia Tahun 1945. Undang-undang Nomor 22 Tahun 2004 tentang Komisi Yudisial.

Undang-undang Nomor 24 Tahun 2003 tentang Mahkamah Konstitusi.

Undang-undang Nomor 3 Tahun 2009 tentang Mahkamah Agung.

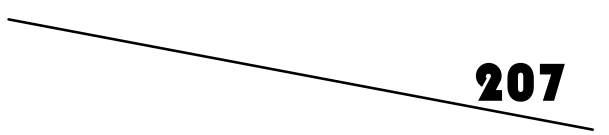

